https://helda.helsinki.fi

\title{
Taxonomic review of Macraulacinae and Eucneminae (Coleoptera: Eucnemidae) from Korea
}

\section{Seung, Jinbae}

\section{7}

Seung , J , Lee , S \& Muona , J 2017 , ' Taxonomic review of Macraulacinae and Eucneminae (Coleoptera: Eucnemidae) from Korea ' , Journal of Asia Pacific Entomology , vol. 20 , no. 2 , pp. 569-575 . https://doi.org/10.1016/j.aspen.2017.03.005

http://hdl.handle.net/10138/309038

https://doi.org/10.1016/j.aspen.2017.03.005

publishedVersion

Downloaded from Helda, University of Helsinki institutional repository.

This is an electronic reprint of the original article.

This reprint may differ from the original in pagination and typographic detail.

Please cite the original version. 


\title{
Taxonomic review of Macraulacinae and Eucneminae (Coleoptera: Eucnemidae) from Korea
}

\author{
Jinbae Seung a, Seunghwan Lee ${ }^{a, b, *}, J_{y r k i}$ Muona ${ }^{c}$ \\ a Insect Biosystematics Laboratory, Department of Agricultural Biotechnology, Seoul National University, Seoul 151-921, Republic of Korea \\ ${ }^{\mathrm{b}}$ Research Institute for Agricultural and Life Sciences, Seoul National University, Seoul 151-921, Republic of Korea \\ c Finnish Museum of Natural History, Zoological Museum, FIN-00014, University of Helsinki, Finland
}

\section{A R T I C L E I N F O}

\section{Article history:}

Received 16 November 2016

Revised 6 March 2017

Accepted 7 March 2017

Available online 8 March 2017

\section{Keywords:}

Taxonomy

Macraulacinae

Eucneminae

Feaia

New combination

Korea

\begin{abstract}
A B S T R A C T
Three eucnemid genera and species are recognized for the first time from Korea: Euryptychus vicinus Fleutiaux, 1923, Fornax consobrinus Hisamatsu, 1963, and Feaia nipparensis (Hisamatsu, 1957) new combination (= Heterotaxis nipparensis Hisamatsu, 1957). A key to species, diagnoses, redescriptions, and photographs of diagnostic characters are provided for known Korean species.

(c) 2017 Published by Elsevier B.V. on behalf of Korean Society of Applied Entomology, Taiwan Entomological Society and Malaysian Plant Protection Society.
\end{abstract}

\section{Introduction}

The subfamily Macraulacinae Fleutiaux, 1923 (Coleoptera: Eucnemidae) is comprised of 942 species belonging to 103 genera in eight tribes worldwide (Muona, 1993, 2011). Among them, 35 species of 15 genera in four tribes have been presented in Palaearctic region (Muona, 2007). Up to now, only one species of Macraulacinae, Dromaeolus marginatus Hisamatsu, 1965, has been known from the Korean peninsula (Suzuki, 2014). Another subfamily Eucneminae Eschscholtz, 1829 consists of 178 genera and 36 species worldwide, including 12 Palaearctic species of four genera (Muona, 1993, 2007, 2011). No Eucnemine beetle was previously known from Korea.

Macraulacinae is characterized by deep basally open lateral antennal grooves and rows of spines on lateral surfaces of meso- and metatibiae. The great majority of Macraulacine genera have males with basal sexcombs on first protarsomere. All Korean species belong to such genera. Eucnemine species have deep lateral antennal grooves and superficially they resemble Macraulacinae species. Contrary to these, they never have sex-combs on first protarsomere of male and lack tibial spinerows. Also, they can be differentiated from Macraulacine species by basally closed or constricted, often very deep lateral antennal grooves. Both the male and female genitaliae and the larval structure are very

\footnotetext{
* Corresponding author at: Insect Biosystematics Laboratory, Department of Agricultural Biotechnology, Seoul National University, Seoul 151-921, Republic of Korea

E-mail address: seung@snu.ac.kr (S. Lee).
}

different from those of Macraulacinae (Muona, 1993, 2000; Muona and Teräväinen, 2008; Otto and Gruber, 2016).

In this study, we review Korean Macraulainae with two unrecorded species, Euryptychus vicinus Fleutiaux, 1923 and Fornax consobrinus Hisamatsu, 1963. Also, we add Feaia nipparensis (Hisamatsu, 1957) new comb., originally placed in the genus Heterotaxis Bonvouloir, 1871 of Macraulacinae. $H$. nipparensis should be transferred to the genus Feaia, based on following characters: basally constricted antennal grooves; meso- and metatibia without rows of spines; male protarsomere 1 without sex-comb; fifth abdominal ventrite pointed in male, truncate in female; highly modified aedeagus. Because of the original descriptions for each species are insufficient, they are redescribed in the present study. A key to species of Korean Macraulacinae and Eucneminae, diagnoses, redescriptions, and photographs of diagnostic characters are provided.

\section{Materials and methods}

Most samples examined for this study were collected by the flight intercept trap (FIT, window trap) or with naked eye from 2015 to 2016, and stored in the insect collection of Seoul National University (SNU, Seoul, Korea). Additional materials are also available from the Korea National Arboretum (KNA, Pocheon, Korea). The abbreviations for collection localities are as follows: SL, Seoul; GG, Gyeonggi-do; GW, Gangwon-do. 
Collected samples were preserved in 95\% alcohol (ETOH) and made into dried specimens by double mounted method. Antennae, tarsi of hind leg, and aedeagus were dissected with micro-pin for examination. The dried specimens were observed under a microscope, Leica S8APO. Photographs were taken by a digital camera, CANON EOS-600D, through MP-E $65 \mathrm{~mm}$ lens. Several layers of pictures were stacked by software, Zerene Stacker 1.04, for improving the resolution.

The morphological terminology follows Muona (1993). The dates for Bonvouloir's world revision follow Muona \& Malinen (in press).

\section{Systematic accounts}

Family Eucnemidae Eschscholtz, 1829.

Key to the species of Korean Macraulacinae and Eucneminae:

1. Antennomeres 9-11 enlarged; hypomeral antennal grooves absent-Euryptychus vicinus

-Antennomeres 9-11 simple; hypomeral antennal grooves well-developed laterally -2

2. Metacoxal plate strongly widened inward; apical margin of fifth abdominal ventrite more or less narrowly rounded in both sexes; male protarsomere 1 with basal sex-comb-3

-Metacoxal plate subparallel-sided; apical margin of fifth abdominal ventrite sharply pointed in male, truncated or weakly concave in female; male protarsomere 1 without sex-comb-Feaia nipparensis new comb.

3. Body mostly chestnut to dark brown; basal width of metepisternum narrower than outer margin of metacoxal plate-Fornax consobrinus

-Body mostly black; basal width of metepisternum wider than outer margin of metacoxal plate-Dromaeolus marginatus.

Subfamily Macraulacinae Fleutiaux, 1923.

Macraulacinae Fleutiaux, 1923. Type genus: Macraulacus Bonvouloir, 1871.

Diagnosis. Body usually elongate; labrum attached underneath frontoclypeal region; pronotal lateral ridges complete; hypomeron with lateral antennal groove or simple; mesepimeron fused with mesepisternum; protibia with one apical spur; meso- and metatibia with row of spines on lateral surfaces; median lobe of aedeagus fused with lateral lobes (Muona, 1993, 2000).

Tribe Euryptychini Mamaev, 1976. 1852.

Euryptychini Mamaev, 1976. Type genus: Euryptychus LeConte,

Diagnosis. Body elongate, slightly convex; antennomeres 9-11 enlarged, mostly longer in male than those of female; hypomeral antennal grooves absent; first protarsomere with sex-comb in male; fourth tarsomere simple; abdominal ventrites connate; median lobe of aedeagus bifurcated at apex (Muona, 1993, 2000).

Genus Euryptychus Leconte, 1852.

Euryptychus LeConte, 1852. Type species: Eucnemis heterocerus Say, 1836.

Dyscolocerus Bonvouloir, 1871. Type species: Dyscolocerus subnitidus Bonvouloir, 1875.

Diagnosis. Body elongate and slightly convex; clypeus rounded at apical margin; third antennomere elongate; antennomeres 4-8 subequal, wider than long; antennomeres 9-11 enlarged; pronotum slightly convex, strongly narrowed anteriad; pronotal posterior angles sharply produced posteriad; metepisternum subparallel-sided; metacoxal plate strongly expanded inward; fourth tarsomere slightly oblique; aedeagus elongate and slender; median lobe of aedeagus deeply bifurcated at apex (Leconte, 1852; Bonvouloir, 1875; Hisamatsu, 1985; Muona, 2000).

Euryptychus vicinus Fleutiaux, 1923 (Fig. 1).
Euryptychus vicinus Fleutiaux, 1923: 324.

Redescription. Female 7.7-9.4 mm long and 2.2-2.8 mm wide; Body elongate, slightly convex; mostly black with orange brownish tarsi; fairly glossy and covered with yellowish gray hairs on dorsum; dull and densely pubescent with golden pubescence on ventral surface. Head transverse, moderately inserted into prothorax; mostly with circular and regular punctures, denser at frontoclypeal region; compound eyes undivided; frons with a short longitudinal groove at middle; clypeus simply rounded at apical margin, width of clypeal apex approximately twice wider than distance between antennal sockets (Fig. 1e). Antennae enlarged apically, almost exceeding hypomeron, and covered with yellowish brown pubescence; first antennomere elongate and stout; second antennomere obconical, about 1.5 times longer than fourth; third antennomere elongate, rectangular, and as long as antennomeres 4-5 combined; antennomeres 4-8 subequal, wider than long; antennomeres 9-11 enlarged; ninth antennomere about 1.6 times longer than wide, about 1.1 times longer than tenth; apical antennomere oblong, about 1.2 times longer than previous (Fig. 1d). Pronotum slightly convex, as long as wide, subparallel-sided, abruptly narrowed anteriad from basal three-fifth, and arcuate at anterior margin; with finer and sparser punctures than head; with a weak mediolongitudinal groove at basal half; a pair of weak dimples presented at middle of basal two-third; antiscutellar area slightly impressed and notched; pronotal posterior angles sharply produced posteriad, obviously exceeding antiscutellar area. Scutellum trapezoidal, as long as wide, gradually narrowed posteriad, and slightly rounded at apex; sparsely punctate; rarely pubescent. Elytra conjointly with width to length as about 1 to 2.3; parallel-sided, gradually narrowed near apices; fairly striated, with deep punctures; interstriae slightly convex; with several large and deep punctures near apices; simply rounded at apices. Prosternum rectangular, with curved sides, and slightly widened anteriad; mostly with finer punctures than head, slightly rougher and denser at anterior and lateral regions; prosternal process narrow, gradually tapered and oblique posteriad; hypomeron punctate as prosternum; with rugose surface at posterior fossae; hypomeral antennal grooves absent (Fig. 1g). Mesosternum with rough and dense punctures; mesepimeron fused with mesepisternum, coarsely punctate, especially at posterior region. Metasternum with dense punctures than prosternum; metepisternum subparallel-sided, slightly widened posteriad, and widest width about 2.5 times wider than outer margin of metacoxal plate (Fig. 1h); metacoxal plate strongly expanded inward, medially about five times wider than laterally (Fig. 1j). Legs fairly stout; tarsi slender; first metatarsomere about 1.2 times longer than secondfourth combined, second about 1.2 times longer than third, fifth about 1.1 times longer than second; claws simple (Fig. 1i). Abdomen strongly connate; punctate as metasternum; fifth ventrite simply rounded at apical margin (Fig. 1f).

Specimens examined. $<$ GG $>1$ \& (KNA), Gwangnung National Arboretum, Sohol-eup, Pocheon-si, 29. vi. 2007, leg. T. S. Kwon; 1 (KNA), Gwangnung National Arboretum, Sohol-eup, Pocheon-si, 06. viii. 2008, leg. T. S. Kwon. $<\mathbf{G W}>1$ ᄋ (SNU), Cheonmi-ri, Bangsan-myeon, Yanggu-gun, 16. v. 2015, leg. S. H. Lee; 1 (SNU), Beopheung-ri, Sujumyeon, Yeongwol-gun, 02-16. vii. 2015, leg. Seung and Lee by FIT.

Distribution. Korea (new record), Japan, Russia (Far East).

Remarks. Euryptychus vicinus is similar to E. lewisi, but can be distinguished by length of third antennomere: third antennomere as long as antennomeres 4-5 combined in E. vicinus, while shorter in E. lewisi. A female individual was observed wandering at surface of dead tree in May.

Tribe Macraulacini (Fleutiaux, 1923).

Macraulacinae Fleutiaux, 1923. Type genus: Macraulacus Bonvouloir, 1871.

Fornaxini Cobos, 1964. Type genus: Fornax Laporte, 1835.

Dromaeolini Leiler, 1976. Type genus: Dromaeolus Kiesenwetter, 1858.

Diagnosis. Body elongate, slightly convex; antennomeres 4-10 subequal; hypomeral antennal grooves well-developed laterally, basally 

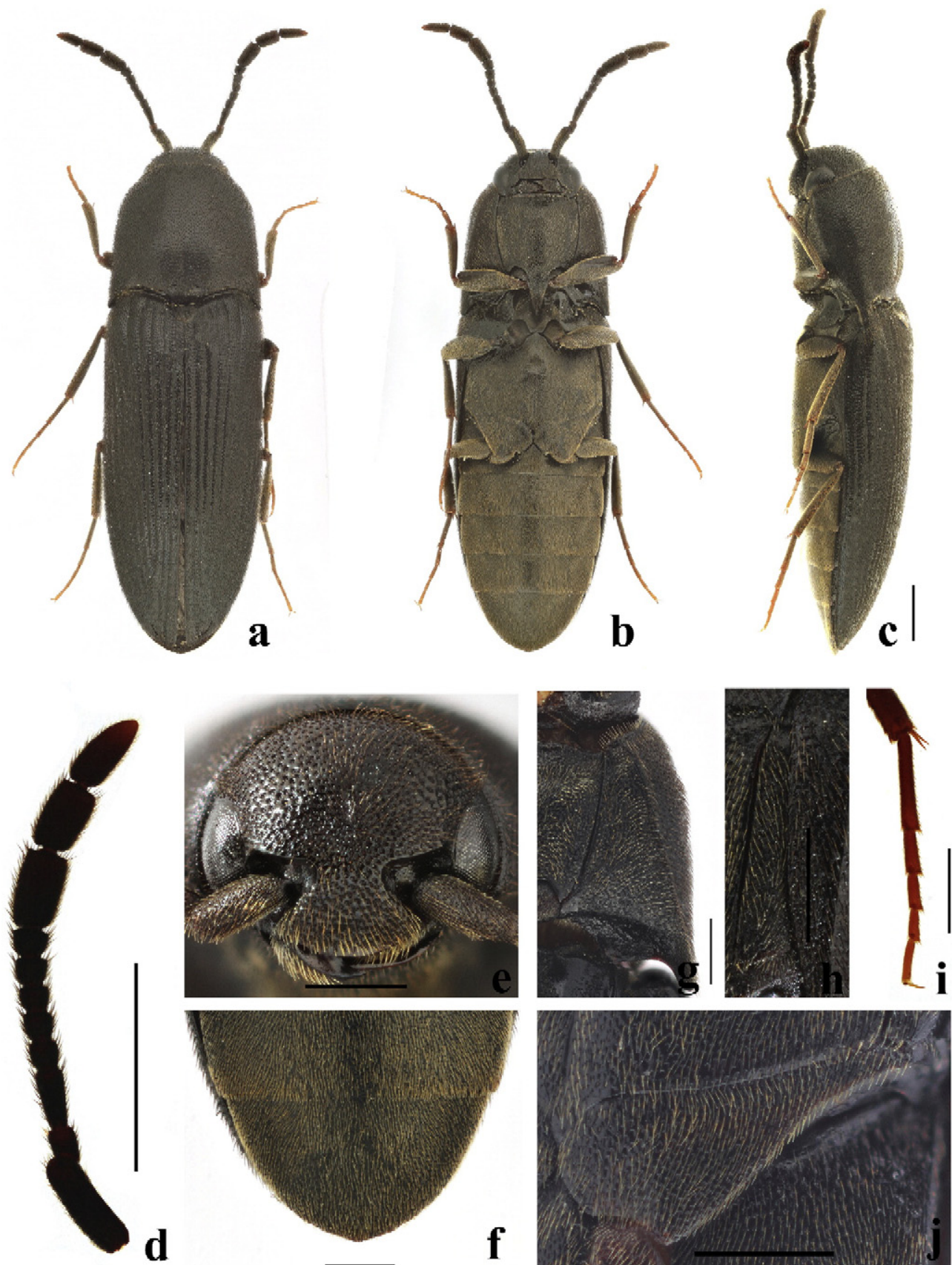

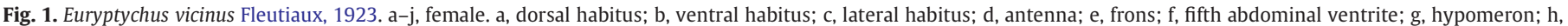
metepisternum; i, metatarsi; j, metacoxal plate (scale bar for a-d: $1 \mathrm{~mm}$; e-j: $0.5 \mathrm{~mm}$ ).

open; first protarsomere with sex-comb in male; fourth tarsomere dilated and bilobed; abdominal ventrites connate; median lobe fused with lateral lobes (Muona, 1993, 2000).

Genus Dromaeolus Kiesenwetter, 1858.

Dromaeolus Kiesenwetter, 1858. Type species: Eucnemis barnabita A. Villa and J. B. Villa, 1838.

Megathambus Reitter, 1911. Type species: Dromaeolus moronita Bonvouloir, 1871.

Melanus Broun, 1881. Type species: Melanus sculptus Broun, 1881.

Diagnosis. Body oblong or elongate, fairly convex; antennae slightly exceeding pronotum, various in form, filiform to serrate; second antennomere shortest or as long as fourth; antennomeres 3-10 weakly toothed at least in male; apical antennomere oblong; pronotum slightly wider than long, strongly sinuated at base; hypomeral antennal grooves well-developed laterally or simple; basal width of metepisternum wider than outer margin of metacoxal plate; metacoxal plate strongly expanded inward; legs slender; fourth tarsomere dilated, slightly shorter than third, and about twice wider fifth; fifth abdominal ventrite simply rounded or pointed at apical margin (Bonvouloir, 1871; Fleutiaux, 1923; Hisamatsu, 1985; Muona, 2000).

\section{Dromaeolus marginatus Hisamatsu, 1965.}

Dromaeolus marginatus Hisamatsu, 1965: 134.

Diagnosis. Body elongate and slightly convex; head moderately convex; clypeus strongly narrowed basally, clypeal base about one-third as wide as distance to eye; antennae weakly serrate, exceeding pronotal posterior angles; pronotum with indistinct medio-longitudinal groove at basal half; elytral ratio of width to length as about 1 to 2.1-2.2; hypomeral antennal groove well-developed laterally; metacoxal plate strongly expanded inward; fifth abdominal ventrite weakly pointed or rounded (Hisamatsu, 1965, 1985). 
Specimens examined. Korean specimens were not available for this study.

Distribution. Korea (Mt. Seorak, Ganwon-do), Japan (Hachijo Island), Taiwan.

Remarks. Suzuki (2014) reported D. marginatus from Korea, but we couldn't identify this species in the present study.

Genus Fornax Laporte, 1835.

Fornax Laporte, 1835. Type species: Fornax ruficollis Laporte, 1835.

Filifornax Fleutiaux, 1945. Type species: Fornax leseleuci Fleutiaux, 1899.

Monilifornax Fleutiaux, 1945. Type species: Fornax lambertoni Fleutiaux, 1926.

Diagnosis. Body elongate, slightly convex, narrowed anteriad and posteriad; clypeus simply rounded or sinuate at apical margin; antennae filiform; second antennomere shortest; third antennomere elongate; antennomeres 4-10 gradually slenderized toward apex; apical antennomere strongly elongate; hypomeral antennal grooves well-developed laterally; basal width of metepisternum narrower than outer margin of metacoxal plate; metacoxal plate strongly expanded inward; fourth tarsomere short, bilobed; median lobe of aedeagus fused with lateral lobes; lateral lobes with basally attached secondary lateral lobes (Laporte, 1835; Bonvouloir, 1871; Hisamatsu, 1985; Muona, 2000).

Fornax consobrinus Hisamatsu, 1963 (Fig. 2).

Fornax consobrinus Hisamatsu, 1963: 26.

Redescription. Male 7.1-8.9 mm long and 2.0-2.3 mm wide; Body elongate, subcylindrical, and slightly convex; wholly castaneous; with fairly glossy surface; covered with dense golden pubescence. Head transverse, moderately inserted into prothorax; mostly with circular and regular punctures, finer at frontoclypeal region; compound eyes large, well-developed, and undivided; clypeus broadly rounded at apical margin, width of clypeal apex about 2.6 times wider than distance
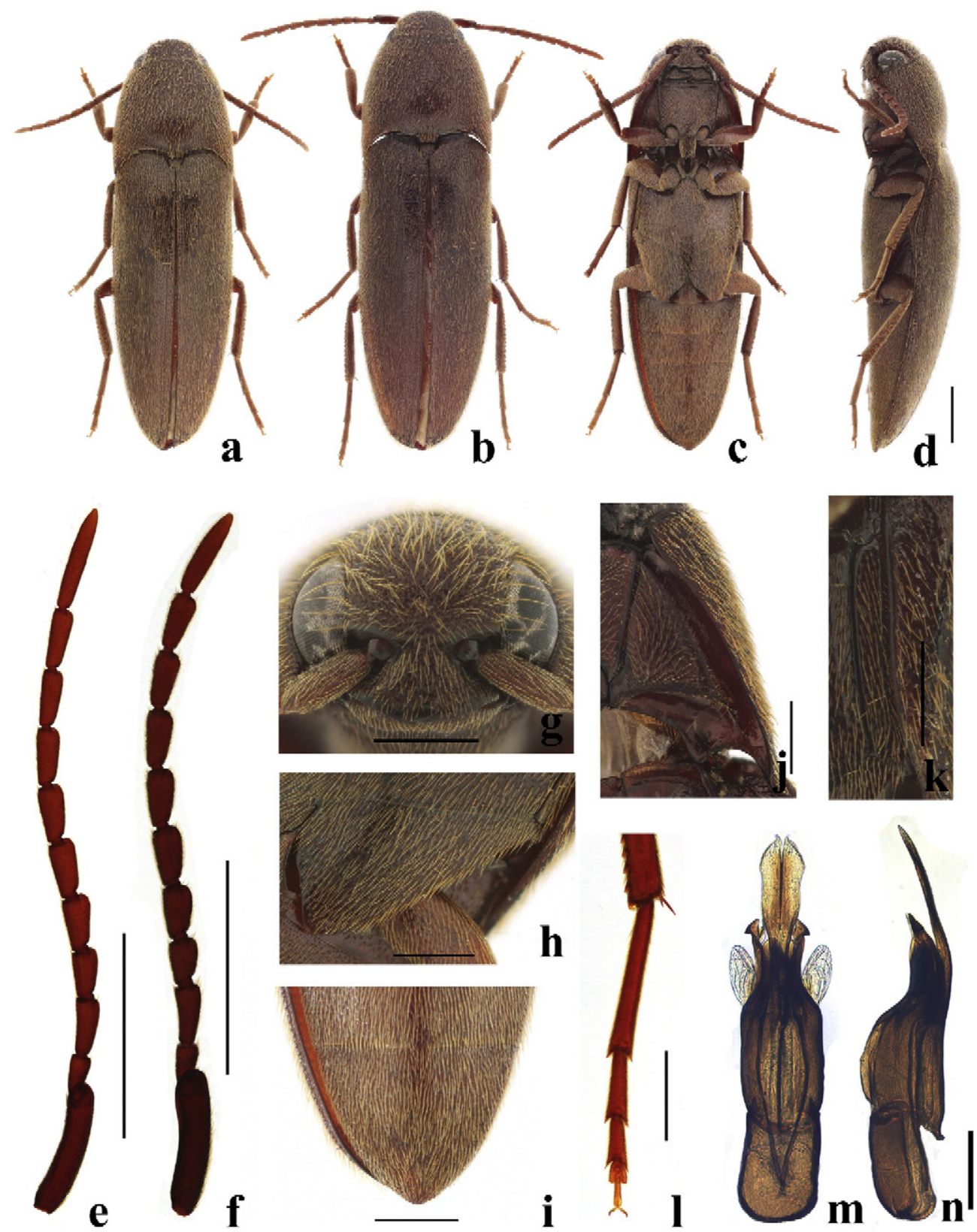

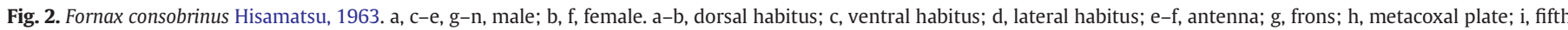
abdominal ventrite; j, hypomeron; k, metepisternum; l, metatarsi; m, aedeagus in dorsal view; n, aedeagus in lateral view (scale bar for a-f: 1 mm; g-n: 0.5 mm). 
between antennal sockets (Fig. 2g). Antennae filiform, almost exceeding posterior margin of metepisternum, covered with short yellowish pubescence; first antennomere elongate and stout; second antennomere obconical, shortest; third antennomere elongate, about twice longer than wide, approximately 1.5 times longer than second, and about 1.3 times longer than fourth; antennomeres 4-10 gradually lengthened and slenderized toward apex; apical antennomere strongly elongate, about five times longer than wide, and approximately 1.85 times longer than previous (Fig. 2e). Pronotum slightly convex, as long as wide, gradually narrowed anteriad, and weakly arcuate at anterior margin; mostly punctate as head, finer and denser at anterior and posterior regions; antiscutellar area slightly impressed and straight; pronotal posterior angles sharply produced, distinctly exceeding posterior margin of antiscutellar area. Scutellum trapezoidal, about 1.2 times wider than long, gradually narrowed posteriad, and almost truncated at apex; roughly punctate; densely pubescent. Elytra conjointly with width to length as about 1 to 2.5 ; subparallel-sided, gradually narrowed posteriad; weakly striated, with irregular and shallow punctures; interstriae almost flattened; with several large and deep punctures near apices; simply rounded at apices. Prosternum quadrate, subparallel-sided, and slightly widened anteriad; with regular and sparse punctures; prosternal process stout, parallel sided, gradually tapered and declined near apex; hypomeron with more shallow and irregular punctures than prosternum; with wrinkled surface at posterior fossae; hypomeral antennal grooves well-developed laterally, basally open, slightly wrinkled, and fairly glabrous (Fig. 2j). Mesosternum roughly punctate; mesepimeron fused with mesepisternum, with scattered punctures, especially at posterior region. Metasternum with punctures as prosternum; with two pairs of longitudinal grooves at both sides of anterior margin; with a weak medio-longitudinal groove at middle, not reaching anterior margin; metepisternum subparallel-sided, gradually widened posteriad, and widest width about 1.3 times wider than outer margin of metacoxal plate (Fig. 2k); metacoxal plate strongly expanded inward, medially approximately eight times wider than laterally (Fig. 2h). Legs moderate in length; femur robust; tibiae and tarsi fairly slender; first metatarsomere about 1.2 times longer than second-fourth combined, second about 1.5 times longer than third and approximately 1.7 times longer than fifth; claws simple (Fig. 2l). Abdomen strongly connate; mostly punctate as metasternum, with coarser and denser punctures at posterior region of fifth ventrite; fifth ventrite narrowly rounded at apical margin (Fig. 2i). Aedeagus elongate, about 3.75 times longer than wide; median lobe elongate, strongly compressed dorsoventrally, gradually expanded distally, deeply and narrowly bifurcated at apex; lateral lobes obviously shorter than median lobe, with apical tooth, with laterally attached secondary lateral lobes; secondary lateral lobes foliated; basal strut reaching basal piece; basal piece rectangular, about 1.28 times longer than wide, and almost one-fourth of length of aedeagus (Fig. $2 \mathrm{~m}-\mathrm{n}$ ).

Sexual dimorphism. Female very similar to male, but can be distinguished by the following characters: clypeus more wide at base than those of male, width of clypeal apex about 2.2 times wider than distance between antennal sockets; antennae relatively shorter, almost reaching anterior margin of metepisternum; third antennomere about 1.45 times longer than fourth; antennomeres 4-10 more stubby; apical antennomere less elongate, about 4.1 times longer than wide, and approximately 1.7 time longer than previous (Fig. 2f).

Specimens examined. $<$ SL $>1 O^{7}(\mathrm{SNU})$, Mt. Gwanak, Daehak-dong, Gwanak-gu, Seoul-si, 19. vi. 2015, leg. J. B. Seung; 4 O’, 7 १ (SNU), Mt. Gwanak, Daehak-dong, Gwanak-gu, Seoul-si, 11. iv. 2016, leg. J. B. Seung (09. v. 2016, adult emergence).

Distribution. Korea (New record), Japan, Russia (Far East).

Remarks. Fornax consobrinus is closely related to F. nipponicus, but can be distinguished by ratio of third antennomere to fourth in male: third antennomere about 1.3 times longer than fourth in F. consobrinus, while about twice as long in F. nipponicus. Also F. consobrinus is differentiated from F. victor by its simple claws. Straight-formed larvae in last stage were collected between sapwoods of dead Robinia pseudoacacia in April and emerged as adults in May. Adults are clicking, well-flying, and active-running.

Subfamily Eucneminae Eschscholtz, 1829.

Eucnemidès Eschscoltz, 1829. Type genus: Macraulacus Ahrens, 1812.

Diagnosis. Body elongate or cylindrical; labrum attached underneath frontoclypeal region; pronotal lateral ridges complete; hypomeron with lateral antennal groove; mesepimeron fused with mesepisternum; protibia with one apical spur; meso- and metatibia flattened, without lateral rows of spines; aedeagus highly modified (Muona, 1993, 2000).

Tribe Mesogenini Muona, 1993.

Mesogenini Muona, 1993: 49. Type genus: Mesogenus Bonvouloir, 1871.

Diagnosis. Body elongate, cylindrical and usually convex; antennomeres 4-10 subequal, usually increasingly dentate toward apex; hypomeral antennal grooves well-developed laterally, basally closed or constricted; tarsi often delicate, male first protarsomere without sex-comb; abdominal ventrites connate; median lobe modified (Muona, 1993; Muona \& Malinen, in press).

\section{Genus Feaia Fleutiaux, 1896.}

Feaia Fleutiaux, 1896: 540. Type species: Feaia dubia Fleutiaux, 1896.

Diagnosis. Body oblong, cylindrical, and strongly convex; clypeus trapezoidal, feebly trilobed or simply rounded at apical margin; antennae serrate or filiform, not exceeding pronotum; second antennomere slightly shorter than third; elytra strongly striated; hypomeral antennal grooves well-developed laterally; metepisternum strongly expanded posteriad; metacoxal plate subparallel-sided; lateral surfaces of mesoand meta tibiae with setae; fifth ventrite truncated or beaked at apical margin (Fleutiaux, 1896; Muona, 1993; Otto, 2016).

Feaia nipparensis (Hisamatsu, 1957) NEW COMBINATION (Fig. 3).

Heterotaxis nipparensis Hisamatsu, 1957: 45.

Redescription. Female 5.7-6.2 $\mathrm{mm}$ long and 1.9-2.1 mm wide; Body oblong, cylindrical, and strongly convex; mostly black; antennae dark brown; mouthparts, pronotal anterior margin, posterior angles, prosternal process, elytral base, and fifth abdominal ventrite tinged with ferruginous; tibiae yellowish brown; with dull surface; covered with golden pubescence. Head strongly inserted into prothorax, barely visible in dorsal view; mostly with circular and irregular punctures, finer and coarser near clypeus; frontoclypeal region slightly depressed; clypeus trapezoidal, sinuate and rounded at apical margin, width of clypeal apex about 1.6 times wider than distance between antennal sockets (Fig. 3e). Antennae strongly serrate, almost reaching anterior margin of metepisternum, covered with yellowish brown pubescence; first antennomere oblong, robust, and produced at apex; second antennomere obconical and shortest; third antennomere trapezoidal, as long as wide, and about 1.3 times longer than second; fourth antennomere about 1.1 times longer than third; antennomeres 4-10 subequal in length, gradually strongly toothed toward apex; apical antennomere oblong, about 2.3 times longer than wide, and about 1.7 times longer than tenth (Fig. 3d). Pronotum strongly convex, as long as wide, abruptly narrowed anteriad from basal half, and arcuate at anterior margin; mostly with rougher and coarser punctures than head, slightly larger at lateral and posterior regions; with a medio-longitudinal groove in full length of pronotum, more or less indistinct near anterior margin; antiscutellar area straight; pronotal posterior angles dully produced, exceeding posterior margin of antiscutellar area. Scutellum tongue-like, about 1.2 times longer than wide, parallel-sided, narrowed posteriad near apex, and broadly rounded at apex; non-punctures and glabrous. Elytra conjointly with width to length as about 1 to 2.1; subparallel-sided, gradually narrowed posteriad; distinctly striated, with deep and large punctures; interstriae convex; simply rounded at apices. Prosternum strongly transverse, with curved sides, and widened anteriad; mostly with larger, sparser, and more regular punctures than head; prosternal process narrow, parallel-sided, and gradually declined 

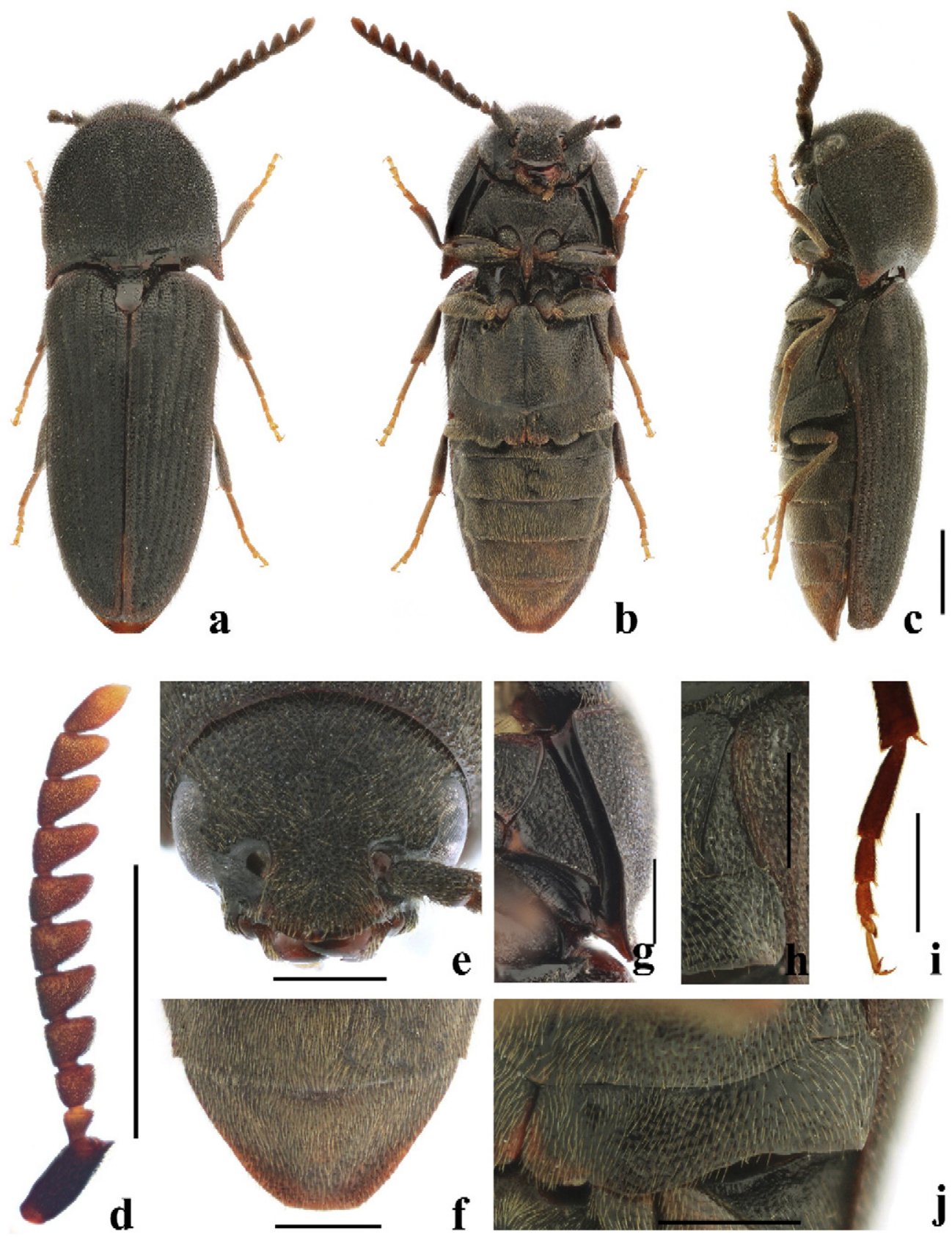

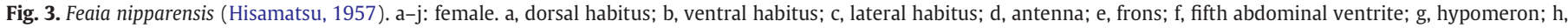
metepisternum; i, metatarsi; j, metacoxal plate (scale bar for a-d: $1 \mathrm{~mm}$; e-j: $0.5 \mathrm{~mm}$ ).

and pointed near apex; hypomeron with larger and rougher punctures than prosternum; with rugose surface at posterior fossae; hypomeral antennal grooves well-developed laterally, open at posterior margin, barely punctate, and glabrous (Fig. 3g). Mesosternum with regular and dense punctures; mesepimeron fused with mesepisternum, coarsely punctate, especially at posterior region. Metasternum mostly with finer, denser, and more regular punctures than prosternum, gradually sparser at lateral region; with a medio-longitudinal groove in full length of metasternum; metepisternum triangular, distinctly widened posteriad, and widest width about three-fifth of outside of metacoxal plate (Fig. 3h); metacoxal plate parallel-sided, slightly concave at middle (Fig. 3j). Legs moderate in length; tarsi slender; first metatarsomere as long as second-fourth combined, second about 1.3 times longer than third and as long as fifth (Fig. 3i); claws simple. Abdomen strongly connate; with fine punctures than metasternum; each ventrites distinctly convex at middle; fifth ventrite truncated at apical margin (Fig. 3f).
Specimens examined. $<\mathbf{G W}>2$ @ (SNU), Suha-ri, Daegwanryeongmyeon, Pyeongchang-gun, 14. vii. 2015, leg. J. B. Seung.

Distribution. Korea (new record), Japan.

Remarks. Feaia Fleutiaux has remained obscure ever since its description. Muona (1987) established its identity by fixing the type species. Muona (1991: 172) included five species in Feaia, but without any supporting data. Later Muona (1993: 50) discussed the question in more detail, but inadvertently did not mention Heterotaxis nipparensis.

The Korean female specimen of Feaia nipparensis differs slightly from studied Japanese ones. It has a slightly more elongated frontoclypeal region, being higher than wide, and slightly slenderer antennae. These differences can be judged better only after studying more material, especially also the males.

Adults and cadavers of $F$. nipparensis were observed under bark of dead Betula davurica. 


\section{Acknowledgments}

We appreciate Dr. Boohee Jung (Korean Entomological Institute, Korea University, Korea), Ms. Hyanggi Ahn, and Mr. Seunghyun Lee for assistance to collect samples for this study. This work is supported by a grant from the National Institute of Biological Resources (NIBR), funded by the Ministry of Environment (MOE) of the Republic of Korea (NIBR201601203).

\section{References}

Ahrens A., 1812. Beitrâge zur Kenntnis deutscher Kâfer. 8. (Mit Bemerkungen von Kunze). Neue Schriften der Naturforschenden Gesellschaft zu Halle 2 (2), 1-40, pis. 2.

Bonvouloir, H.A. de, 1871. Monographie de la Famille des Eucnémides, 1st part. Annales de la Société entomologique de France 40 Supplement, 1-288, pis. 1-21.

Bonvouloir, H.A. de, 1875. Monographie de la Famille des Eucnémides, 4th part. Annales de la Société entomologique de France 40 Supplement, 561-907, pis. 37-42.

Broun, T., 1881. Manual of the New Zealand Coleoptera. Part II. Georg Didsbury, Wellington, pp. 653-744.

Cobos, A., 1964. Materiales para el studio de la familia Eucnemidae. Primera parte (Coleoptera). 40. Eos, Revista Espaňola de Entomología, pp. 289-435.

Eschscholtz, J.F.G., 1829. Elaterites, Eintheilung derselben in Gattungen. Thon's Entomologisches Archiv. 2(1), pp. 31-35.

Fleutiaux, E., 1896. Viaggio di Leonardo Fea in Birmania e regioni vicine. Annali del Museo Civico di Storia Naturale di Genova. 36, pp. 533-544.

Fleutiaux, E., 1899. Eucnémides et Elaterides récoltés à l'ile Nias par M.U. Raap en 1897 et 1898. Annali del Museo Civico di Storia Naturale di Genova. 39, pp. 569-572.

Fleutiaux, E., 1923. Les Melasidae du Japon. Annales de la Société Entomologique de France. 91, pp. 291-328.

Fleutiaux, E., 1926. Catalogue methodique des Melasidae (Eucnemidae) de Madagascar. Encyclopedie Entomologique Paris Ser BI Col. 1, pp. 91-121.

Fleutiaux, E., 1945. Revision des eucnémides Africains. Abeille, Journal d'Entomologie 34 149-274.

Hisamatsu, S., 1957. A new species of Eucnemidae from Japan (Coleoptera). Akitu. 6, pp. $45-46$.

Hisamatsu, S., 1963. Six new species of Eucnemidae from Japan (Coleoptera). Transactions of the Shikoku Entomological Society. 8, pp. 26-34.

Hisamatsu, S., 1965. Some beetles from Formosa. Special Bulletin of Lepidopterological Society of Japan 1, pp. 130-140.
Hisamatsu, S., 1985. Eucnemidae. Colored illustrations of the Coleoptera of Japan, vol. III (Osaka), 40-51, pis. 8-9.

Kiesenwetter, E.A.H. von, 1858. Naturgeschichte der Insecten Deutschlands. Erste Abtheilung. Coleoptera. Vierter Band. Nicolaische Verlagsbuchhandlung, Berlin, pp. 179-211.

Laporte, F.L.N., 1835. Etudes entomologiques, ou descriptions d'insectes nouveaux et observations sur la synonymie. Revue Entomologique 3, 157-181 G. Silberman.

Leconte, J.L., 1852. Synopsis of the eucnemides of temperate North America. Proc. Acad. NAtl. Sci. Pila. 6, 45-49.

Leiler, T.E., 1976. Zur Kenntnis der Entwicklungsstadien und der Lebensweise nord und mitteleuropaischer Eucnemiden (Col.). Entomologische Blatter. 72 (1), pp. 10-50.

Mamaev, B.U., 1976. Morphologicheskie typy lichinok zhukov-drevoedov (Coleoptera, Eucnemidae) i ikh evolutionnoe znachenie. Evolutionnaya morphologya lichinok nasekomykh. pp. 138-155.

Muona, J., 1987. The generic names of the beetle Family Eucnemidae (Coleoptera). Entomologica Scandinavica 18, 79-92.

Muona, J., 1991. The Eucnemidae of South-east Asia and the Western Pacific. a biogeographical study. Aust. Syst. Bot. 4, 165-182.

Muona, J., 1993. Review of the phylogeny, classification and biology of the family Eucnemidae (Coleoptera). Fauna Entomol. Scand. 44, 1-133 Supplement.

Muona, J., 2000. A revision of the Nearctic Eucnemidae. Acta Zool. Fenn. 212, 1-106.

Muona, J., 2007. Family Eucnemidae. Catalogue of Palaearctic Coleoptera. 4, pp. 81-86.

Muona, J., 2011. Eucnemidae info. Finnish Museum of Natural History http://dol.luomus. fi:8080/ (Accessed: 11 July 2016).

Muona, J., Malinen, P., 2017. A revision of the genus Temnus Fleutiaux (Coleoptera, Eucnemidae, Galbitini). Zootaxa (in press).

Muona, J., Teräväinen, M., 2008. Notes on the biology and morphology of false click-betle larvae (Coleoptera, Eucnemidae). The Coleopt. Bull. 62 (4), 475-479.

Otto, R., 2016. The false click beetles (Coleoptera: Eucnemidae) of Laos. Entomologica Basiliensia et Collectionis Frey. 35, pp. 181-427.

Otto, R., Gruber, J., 2016. Eucnemid larvae of the Nearctic region. Part VI: Descriptions of the Fifth Instar and Prepupal Larval Stages of Stethon pectorosus LeConte, 1866 (Coleoptera: Eucnemidae: Eucneminae: Mesogenini), with notes on their biology. Insecta Mundi 474, pp. 1-11.

Reitter, E., 1911. Fauna Germanica. Die Kâfer des Deutschen Reiches. Nach der analytischen Methode bearbeitet III, pp. 201-208.

Say, T., 1836. Descriptions of New North American insects, and observations on some already described. Transactions of the American Philosophical Society 6 (NS), 155-190.

Suzuki, W., 2014. Three eucnemid species newly recorded from Korea. Sayabane Newseries. 13, pp. 44-45.

Villa, A., Villa, G.B., 1838. Coleopterorum species novae in hoc altero supplemento commemoratae. Diagnosibus atque observationibus illustratae, pp. 61-63. 